2013-11

\title{
MOLECULAR GENETIC STUDIES OF NEURODEGENERATIVE DISEASE
}

Cooke, T

http://hdl.handle.net/10026.1/3481

10.1136/jnnp-2013-306573.136

Journal of Neurology, Neurosurgery \&amp; Psychiatry

BMJ

All content in PEARL is protected by copyright law. Author manuscripts are made available in accordance with publisher policies. Please cite only the published version using the details provided on the item record or document. In the absence of an open licence (e.g. Creative Commons), permissions for further reuse of content should be sought from the publisher or author. 
MOLECULAR GENETIC STUDIES OF NEURODEGENERATIVE DISEASE

Tim Cooke, CB Carroll, JP Zajicek, S Ellard, KE Morrison. Plymouth University Peninsula Schools of Medicine and Dentistry; University of Exeter Medical School; School of Clinical and Experimental Medicine, College of Medical and Dental Sciences

10.1136/jnnp-2013-306573.136

Introduction Large scale genetic studies such as genome-wide association studies (GWAS) in Parkinson's disease (PD) have revealed genetic susceptibility factors and continue to offer new insights both into the genetics of sporadic disease and its pathogenesis, with the potential for identification of an at-risk population and novel therapeutic targets. However, the methodology importantly requires larger data sets for replication of novel findings.

Aim To develop an independent UK-based PD DNA bank to act as a national and international resource for large-scale genetic studies.

Methods The study was initiated as part of an MRC-funded fellowship in 2009 and was adopted onto the NIHR portfolio in 2010. Patients were included if they had a clinical diagnosis of PD. Section 30 (Mental Capacity Act 2005) approval was also obtained to facilitate recruitment of those with diminished capacity. Patients were excluded if they had previously donated to another national DNA collection, such as PD GEN. Spouse/ carer controls were also recruited. 37 Centres from across the UK took part in the study. DNA was extracted and stored at Royal Devon and Exeter Hospital, Devon.

Results To date over 1370 patients and 530 controls have been recruited to the study. The population characteristics of patients are: $61.1 \%$ male, $98.1 \%$ white, $18.6 \%$ positive family history, 
mean age 70.6 yrs (range 40-98), mean disease duration 5.6 yrs (range 0-49).

Conclusions We have established an independent PD DNA Bank which will have reached its target of 1500 patient samples by April 2013. This sample bank will be similar in size and composition to other national collections such as PD GEN and will act as a valuable resource locally, nationally and for the global PD research community. Its establishment within 3 years is a testimony to the efficient working of the clinical research networks within the UK. 
JNND MOLECULAR GENETIC STUDIES OF NEURODEGENERATIVE DISEASE

Tim Cooke, CB Carroll, JP Zajicek, S Ellard and KE Morrison

J Neurol Neurosurg Psychiatry 2013 84: e2

doi: 10.1136/jnnp-2013-306573.136

Updated information and services can be found at:

http://jnnp.bmj.com/content/84/11/e2.42

\section{These include:}

Email alerting service

Receive free email alerts when new articles cite this article. Sign up in the box at the top right corner of the online article.

Topic Articles on similar topics can be found in the following collections

Collections

Drugs: CNS (not psychiatric) (1774)

Parkinson's disease (619)

\section{Notes}

To request permissions go to:

http://group.bmj.com/group/rights-licensing/permissions

To order reprints go to:

http://journals.bmj.com/cgi/reprintform

To subscribe to BMJ go to:

http://group.bmj.com/subscribe/ 